Peer-Reviewed Article

ISSN: 2162-3104 Print/ ISSN: 2166-3750 Online

Volume 6, Issue 2 (2016), pp. 394-414

(C) Journal of International Students

http://jistudents.org/

\title{
The Development and Validation of the Academic Spoken English Strategies Survey (ASESS) for Non-native English Speaking Graduate Students
}

\author{
Rui M. Schroeder \\ University of the Pacific (USA)
}

\begin{abstract}
This study reports on the three-year development and validation of a new assessment tool-the Academic Spoken English Strategies Survey (ASESS). The questionnaire is the first of its kind to assess the listening and speaking strategy use of non-native English speaking (NNES) graduate students. A combination of sources was used to develop the questionnaire: literature reviews, pilot questionnaire results, feedback from pilot study participants, expert comments, and the author's academic English learning journal. An exploratory factor analysis based on 384 respondents' data was conducted to assess the construct validity. Cronbach's alpha was 0.923, indicating high internal consistency. The study has made a significant contribution because data generated through the use of this questionnaire can provide valuable insights and pedagogical implications.
\end{abstract}

Keywords: academic English, language learning strategies, survey development, non-native English-speaking graduate students

During the last decade, increasing numbers of non-native English speakers have become graduate students at higher-education institutions in the United States. Non-native English speakers 
generally are people whose native language is not English and who do not think of English as their first language, although some of them can use English at the near-native or native levels. In the academic year of 2012-2013, of all graduate students in the U.S., 7\% were neither citizens nor permanent residents of the U.S. Those students are often called "international students" and hold student visas. Some of them are native speakers of English, such as students from Canada and England. Among them, 41\% were from countries where English is not the native language, such as China, Mexico, Brazil, and the Middle East countries. If some students from India could be calculated in as non-native English speakers, this percentage would be even higher (Allum, 2013).

Like their native English-speaking peers, those non-native English speaking (NNES) graduate students must understand formal lectures, give formal presentations, and participate effectively in class discussions and collaborative projects. A certain number of them even have classroom instructional obligations as graduate teaching assistants. Naturally, their listening and speaking competence in English influences their learning, their grades, and their readiness for professional work after graduation. It also often determines the extent to which NNES graduate students contribute to their academic communities.

Hence this question becomes relevant: how do NNES graduate students improve their academic English listening and speaking competence? It can be argued that learners who are strategic (use strategies) with their learning process will be able to learn faster and in a more satisfactory manner. The focus of this article is on language learning and use strategies that non-native graduate students use to accomplish the above-mentioned academic listening and speaking tasks. Language learning and use strategies are defined as specific steps that language learners purposefully take to help them learn or use the target language more effectively. Listening strategies are strategies for listening to and understanding the spoken language, while speaking strategies are strategies for communicating orally in the language.

The article reports the development and validation of a new assessment tool-Academic Spoken English Strategy Survey (ASESS). The rational in developing and validating the ASESS is that 
researchers can use it to measure the strategy use of NNES graduate students. The data generated will provide useful background information, insights, and start-up points for developing strategybased pedagogies, which can potentially help students overcome the listening and speaking hurdles in academic English.

\section{LITERATURE REVIEW}

As Lee (2009) summarized, research has revealed that non-native graduate students are challenged in classroom discussions as they learned English as a foreign language in their own countries and came from "different social-cultural and educational backgrounds" (p. 142). In fact, researchers have found that NNES graduate students experience special difficulties in the following areas of spoken English performance: giving presentations, leading class discussions, and participating in whole-class and group discussions (Cheng, Myles, \& Curtis, 2004; Halic, Greenberg, \& Paulus, 2009; Kim, 2006; Lee, 2009; Zappa-Hollman, 2007), interacting with professors (Choi, 2006), and generally expressing one's ideas and feelings (Halic, Greenberg, \& Paulus, 2009). In addition, NNES graduate students are known to have problems in listening to spoken English in academic settings, such as understanding classroom interactions (Cheng, Myles, \& Curtis, 2004; Miller, 2009). Choi (2006) reported that economic and science majors among Asian graduate students consider listening as their major concern regarding academic English. Erichsen and Doris (2010) found out that many of their research project participants who were NNES graduate students "described great discomfort and acute anxiety about speaking and participating in the traditional classroom setting (at the U.S. university level), (compared with online learning)" (p. 320). They further reported the sense of loneliness and social isolation experienced by those students. It can be assumed that to a large extent, this sense of loneliness and social isolation is due to language barriers, which can be effectively overcome with the use of language learning and use strategies.

Language learning and use strategies are things that language learners purposefully do to help them learn or use the target language more effectively. Two major perspectives of language learning strategies have been developed: the psychological view and the 
social-cultural view. The psychological view looks at learning strategies as mainly involving cognitive processes of the learner. The use of learning strategies is mostly an individual effort to achieve a language learning goal. The social-cultural view starts with the society/community instead of the individual learner as its fundamental unit of observation. With this view, the use of learning strategies is no longer an individualized mental process but a social-cultural phenomenon situated in different contexts (Oxford \& Schramm, 2007).

For the last 30 years, one of the most prominent hypotheses tested in the language learning strategy literature has been that awareness of and intentional use of language learning strategies help make the language learning process more effective (Cohen \& Macaro, 2007; Oxford 2011). As Macaro, Graham, and Vanderplank (2007) wrote, "... [the relationship between] strategy use and successful performance is one of the main claims made by strategy theorists" ( $p$. 168). The research body has generally affirmed this hypothesis (claim) (Huang, 2010). For groups such as undergraduate college students and high school students, the listening and speaking strategies have been shown to relate to language performance in classroom related tasks (Goh, 1998, 2002; Green \& Oxford, 1995; Griffiths, 2003; Nakatani, 2006; Vandergrift, 2003). However, there is a lack of research on strategies used by non-native English speaking students at the graduate level.

Listening and speaking strategies have been successfully measured by means of questionnaires, think-aloud procedures, learner diaries, and interviews among university undergraduates (Lai, 2009; Rohani, 2006), pre-admissions university students (Kyungsim \& Leavell, 2006), secondary school students (Zhang \& Goh, 2006), and even elementary school students (Purdie \& Oliver, 1999). Using results of strategy assessments, it was possible to create targeted strategy-based pedagogies for these groups. For example, Lai's (2009) study of 418 college EFL (English as a Foreign Language) learners indicated that more proficient learners use more language learning strategies and also use more metacognitive and cognitive strategies. Hence the author suggested teaching strategies, especially metacognitive and cognitive strategies to students. Based on her study of private language school students in New Zealand, Griffiths 
(2003) identified "plus" strategies used frequently by more proficient students, which included strategies of managing one's feelings, dealing with ambiguities, and others. Pedagogical suggestions were made based on those findings. To date, however, there has been no prior large-scale research on NNES graduate students' listening and speaking strategy use, although research literature indicates problems in NNES graduate students' listening and speaking performance. No progress can be made in addressing these problems through instruction of strategies, without a valid and reliable instrument to measure strategy use of NNES graduate students in typical academic contexts. Currently, such an instrument has not yet been developed. Thus academic English listening and speaking strategy use at the graduate students' level has been rarely investigated.

The rational in developing and validating the Academic Spoken English Strategies Survey(ASESS) is that researchers can use this instrument to measure the strategy use of non-native Englishspeaking graduate students. From the data generated, an overall picture of this particular group's strategy use emerges, which will provide useful background information, insights, and start-up points for developing strategy-based pedagogies, which can potentially help those students overcome listening and speaking hurdles in academic English.

The rest of the article reports the process and conclusions of the development and validation of the questionnaire, which also includes more information of relevant research. The content validity of the questionnaire was established as the development of the item pool was based on various sources of information, including a review of research, the researcher's journal study of strategy use, feedback from pilot studies, and input from experts. The whole process involved numerous revisions and took about two years to complete. Cronbach's Alpha for each sub-scale was calculated to examine reliability. Finally, an exploratory factor analysis based on responses from 384 participants from the target student group was applied to examine patterns among the interrelationships of the items.

\section{RESEARCH METHOD}

The ASSESS consists of two scales with altogether 39 survey items each of which represents a typical academic English listening or 
speaking strategy. The Likert-Scaled measure is divided into the listening sub-scale (19 items) and the speaking sub-scale (20 items). This format was based on Oxford's (1990) Strategy Inventory for Language Learning (SILL).

\section{Development of the item pool}

According to Oxford (2011), "for detailed assessment of strategy use, structured actual-task strategy questionnaires are among the most relevant and efficient modes" (p. 157). Although the ASESS is not administered immediately after participants complete certain tasks, it focuses on participant's experience of finishing their major academic listening and speaking tasks. Specifically, its items correspond to typical spoken English tasks in U.S. graduate level classrooms, in extracurricular lectures, or at academic conferences. The listening subscale includes listening to professor lecturers, professional conference presentations, peer presentations, and group discussions. The speaking subscale includes giving class and conference presentations and participating in class discussions.

Berends (2006) stated that "drawing on other's research is always relevant but particularly so during the survey instrument design stage" (p. 632). To ensure content validity, the researcher purposefully and carefully examined and consulted various established taxonomies of learning strategies. Oxford's (1990, 2011) taxonomy provides an overarching framework for the questionnaire. In fact, items of the questionnaire represent all of the key strategy types in Oxford's (2011) taxonomy: metacognitive strategies, cognitive strategies, social-interactional strategies, and affective strategies.

Item development of the questionnaire is also substantially informed by a research review of taxonomies of listening and speaking strategies at the secondary or undergraduate college level. With listening strategies, the construction of the questionnaire was partially based on the guidelines of Vandergrift's (2003) taxonomy of metacognitive and cognitive listening comprehension strategies. Vandergrift $(1997,2003)$ presents listening strategy taxonomy of four metacognitive strategies (planning, monitoring, evaluation, and problem identification) and seven cognitive strategies: inferencing, elaboration, imagery, summarization, translation, transfer, and 
repetition. Items of the listening subscale of ASESS correspond to some of the categories suggested by Vandergrift (1997, 2003). Goh's taxonomy (1998) also provided theoretical foundations for the listening subscale, which includes four major top-down cognitive strategies (inferencing, elaboration, prediction and contextualization) and five metacognitive strategies: selective attention, directed attention, comprehension monitoring, real-time assessment of input, and comprehension evaluation. Moreover, the author consulted Oxford's (1990) Strategy Inventory for Language Learning (SILL), and also examined the Metacognitive Awareness Listening Questionnaire (MALQ) developed by Vandergrift, Goh, and Mareschal (2006).

The speaking strategy subscale is substantially informed by the literature of communication strategies, as speaking strategies are commonly referred to as communication strategies (Nakatani \& Goh, 2007). In their comprehensive review of different definitions and taxonomies of communication strategies, Dörnyei and Scott (1997) pointed out two groups of communication strategies: achievement strategies which help the learner achieve original communication goals, and reduction strategies which help the learner avoid solving a communication problem by altering, reducing, or even abandoning the original communication goals. ASESS does not include reduction strategies, because the researcher believes that at the graduate level, the ESL speakers should try to carry out the goal of the conversation instead of abandoning it. The development of the speaking subscale items is also informed by the following: 1) Nakatani and Goh's (2007) review of communication strategies, which stated that negotiation of meaning is an important communication purpose and that the strategies to achieve that negotiation include requesting clarification, checking comprehension, and confirming; 2) Cohen's (1998) method of dividing communication strategies into "before task", "during task" and "after task"; and 3) Nakatani's (2006) Communication Strategy Inventory which included nonverbal strategies such as the use of gestures and facial expressions, and strategies for maintaining fluency such as paying attention to intonation, rhythm, and pronunciation.

The development of the questionnaire has been considerably informed by the insights from an academic English learning journal 
done by the researcher, who was a NNES graduate student at the time (Author, 2014). The researcher recorded her academic spoken English experiences and strategy use during one semester of graduate study in 2009, at a large research university in the U.S. The study provided one more piece of evidence that academic spoken English is important to NNES graduate students and that strategy use can really help improve their classroom performance. The raw materials from this study provided intuitional insights and first-hand research support for the development of the item pool of the questionnaire.

\section{The process of revisions}

Dörnyei (2003) pointed out that due to the importance of the actual wording of the questionnaire items, "an integral part of questionnaire construction is "field testing'." Field testing gives the researcher a chance to collect feedback regarding the questionnaire. During the spring semester of 2009, a first version of the ASSESS was administered to four NNES graduate students in the Education Department of a large research university in the U. S. This sample consisted of two male and two female students. After that the questionnaire was substantially revised. Then the questionnaire was immediately administered to 25 NNES graduate students from a variety of academic fields at the university. After this pilot study, the questionnaire was also significantly revised from wording to format, based on participants' suggestions given as answers to an open-ended question. In Fall semester, 2009, another pilot study was conducted, and six participants were asked to fill out the questionnaire before being interviewed by the researcher. The questionnaire was revised again based on participants' suggestions and a more comprehensive literature review. Thus, three pilot studies with altogether 35 NNES graduate students reveal that the strategy items listed in the questionnaire are quite relevant to this particular student group.

Furthermore, items were carefully evaluated using conclusions from the literature review as criteria. The purpose is to make the instrument reflect the results of up-to-date research, especially strategy use patterns of the more "successful" learners. It is worthy to note that due to the severe paucity of research materials on NNES graduate students' strategy use, the literature review has to mainly include research on high school or college age learners. Open-ended 
questions on the pilot-study questionnaire asked participants to write down new strategies they would use and also suggestions that they had about improving the questionnaire. Those inputs from the participants and also the researcher's own best judgment ensure that this questionnaire is appropriate for NNES graduate students. One method of establishing construct validity is to obtain expert opinions on the relevance of items to the purpose of the questionnaire, on possible wording and interpretation issues. One expert in the English language, who is a teacher and a graduate student, edited the wording of the questionnaire. Another renowned expert of language learning strategies has checked the items.

The final version of ASESS consists of two sections: the first section asks the respondents' basic personal information such as gender, major, undergraduate /graduate standing, country of origin, and institute affiliation. The second section is a 39-item, LikertScaled measure which is divided into the listening sub-scale (19 items) and the speaking sub-scale (20 items). Each item presents a statement about the use of a strategy. For each statement, there are five options ranging from "never or almost never" to "always or almost always". This format was based on Oxford's (1990) Strategy Inventory for Language Learning (SILL). In the listening sub-scale, the items are generally sequenced following the order: before class or presentation, during class or presentation, after class or presentation. In the speaking sub-scale, the items are sequenced from general preparation for speaking tasks, to joining in class discussions, to giving presentations.

\section{Participants}

This study was conducted at a major research-oriented university in the mid-Atlantic region of the United States. This university had approximately 3,600 international students from over 150 countries and over 100 majors and degree programs. Among them, about $65 \%$ came from Asia, $11 \%$ from Europe, $10 \%$ from the Americas, $7 \%$ from near \& Middle East, and 7\% from Africa. About 2000 were graduate students (the year of 2009). Students might regard themselves native speakers of English if they were from Canada or Britain, or from certain areas of India and African countries. Still the majority of those 2000 international graduate 
students were NNES graduate students, of which Chinese and Indian students were the two dominant student groups. Efforts were made to reach as many participants as possible and as diverse as possible in terms of country origins and academic fields.

Altogether, 534 students responded to the on-line ASSESS questionnaire. All of them reported they were non-native English speaking graduate students at the university. The system recorded the time that each respondent spent on the questionnaire. Because 150 respondents spent too little time (less than five minutes) on the questionnaire, their responses were discarded. Therefore, altogether 384 questionnaire responses were deemed as valid data, and a response rate of $19.2 \%$ was achieved.

Of 380 students reporting their standing of graduate studies, $74.5 \%$ were doctoral students, and $25.5 \%$ were master's students. Of 381 students responding about gender, $58.3 \%$ were male; $41.7 \%$ were female. The respondents came from Asia (66.6\%), South America $(10.7 \%)$, Europe $(13 \%)$, the Near East and the Middle East $(7.6 \%)$, and Africa (2.1\%). This makeup roughly reflected the overall makeup of the international graduate student population at the whole institution, except for the fact that no native-English-speaking students from countries such as Britain or Australia participated in the survey. The largest country group represented was India (27\%), followed by China $(24.7 \%)$ and South Korea. The students were from the following academic disciplines: social sciences/humanities/education (28.4\%), sciences (29.2\%), engineering $(31.5 \%)$, business $(8.9 \%)$, and medicine $(1.0 \%)$.

\section{RESULTS}

Factor analysis "is a way of determining the nature of underlying patterns among a large number of variables" (Cohen, Manion \& Morrison, 2000, p.354). An exploratory factor analysis using the survey sample of 384 NNES graduate students was performed to explore the factors underlying both the listening and speaking strategy sub-scales. For the exploratory factor analysis, a principal components method of factor extraction was used and orthogonal rotation of factors was performed using the VARIMAX method. Factor loadings greater than .40 were considered acceptable for simple structure. As recommended by Stern (2010), the Kaiser- 
Meyer-Olkin (KMO) test was performed to determine the factorability of the inter-item correlations (correlation matrix). Since the value of KMO test is 0.889 for the listening strategy sub-scale and 0.898 for the speaking strategy sub-scale, the sample is adequate and the matrix is considered to be very suitable for a factor analysis (Hartas, 2010; Stern, 2010).

\section{Factor analysis of the listening strategy use sub-scale}

Table 1 shows the factors derived from the analysis of the nineteen listening strategy items with the Cronbach's alpha for each factor. After components with eigenvalues <1 were removed, five factors were retained for the participants' listening strategy use. The total percentage of variance accounted for by those five factors is $59.40 \%$. The factors are labeled according to the items that are included. The five factors are: Factor One, Preparing for the Listening Task; Factor Two, Strategies for Keeping on Track while Listening; Factor Three, Strategies for Enhancing Understanding while Listening; Factor Four, Strategies for Clarifying Understanding after Listening; Factor Five, Strategies for Using Technology to Help Listening. In the case of a double loading, the final loading is chosen based on judgments of how relevant the item is to the factors. Appendix B shows the number and name of each factor, the number and general content of every strategy item that loads adequately on that factor, the specific loading of each of the strategy items, and the average frequency of use of the items.

Table 1. Factors of the Listening Strategy Use Sub-scale

\begin{tabular}{lllll}
\hline Factors & Mean & SD & Alpha \\
\hline 1 & $\begin{array}{l}\text { Preparing for the Listening Task } \\
\text { Strategies for Keeping on Track } \\
\text { while Listening }\end{array}$ & 3.79 & 1.28 & 0.78 \\
2 & $\begin{array}{l}\text { Strategies for Clarifying } \\
\text { Understanding after Listening }\end{array}$ & 3.28 & 1.10 & 0.72 \\
3 & $\begin{array}{l}\text { Strategies for Enhancing } \\
\text { Understanding while Listening }\end{array}$ & 3.60 & 1.12 & 0.74 \\
$\begin{array}{l}\text { Strategies for Using Technology } \\
\text { to Help Listening }\end{array}$ & 3.28 & 1.35 & N/A \\
\hline
\end{tabular}


Factor One, Preparing for the Listening Task, includes strategies that can help learners prepare for a listening task, whether it is a class or a presentation. This factor includes five strategies, and three of them are metacognitive strategies; one strategy is affective and another one is cognitive. Metacognitive strategies are often used for planning. The three metacognitive strategies include arriving early, deciding about listening purpose, and predicting the contents (L02, L04, L05). Those strategies are a series of conscious actions that help the learner prepare and plan well for the class or presentation. The one affective strategy is relaxing before class and the one cognitive strategy is checking key words beforehand. All combined, the learner who uses those strategies is preparing for the listening task in various aspects. Therefore, the factor can be referred to as Preparing for the Listening Task.

Factor Two, Strategies for Keeping on Track while Listening, includes strategies that can help learners keep their concentration and focus during the listening activity, especially when they are distracted by difficulties or frustration. For example, learners use metacognitive strategies to keep concentration without giving up (L14) and get back on track and regain concentration when they are distracted (L13). Also, they use affective strategies to encourage themselves when they feel frustrated (L12). If difficulties arise, they will notice the speaker's facial expressions, gestures, and voice changes to help them comprehend the meaning and keep concentrated (L11). This factor is mainly concerned with what learners do in order to keep concentration while listening.

Factor Three, Strategies for Enhancing Understanding While Listening, includes strategies that help learners enhance their understanding while listening. Learners can infer the meaning of words based on the contexts and other cues (L06), check their understanding periodically (L09), adjust their own understanding after they check it (L10), and predict what will be the next message that the presenter will talk about (L08).

Factor Four, Strategies for Clarifying Understanding after Listening, includes strategies that help learners check their understanding after the listening activity is over. Learners need to decide whether they should look up a word during the listening 
activity or after it is over (L15); learners can talk to someone after the presentation to check their understanding (L19); they can ask a question (L16); they can summarize the information that they have heard (L17); finally, they can reflect on the listening experience and think about how to improve their listening next time (L18).

Factor Five, Strategies for Using Technologies to Help Listening, includes one strategy: use laptops to check the meaning of words while listening (L07). In future studies, this factor can include other items, or an independent scale can be developed to assess students' use of technologies.

\section{Factor analysis of the speaking strategy use sub-scale}

Table 2 shows the factors derived from the analysis of the twenty speaking strategy items with the Cronbach's alpha for each factor. After components with eigenvalues $<1$ were removed, four factors were retained for the participants' speaking strategy use. The total percentage of variance accounted for by those four factors is $55.45 \%$. The factors are labeled according to the items that are included. The four factors are: Factor 1, Strategies for Seeking Opportunities to Speak in Class; Factor 2, Strategies for Making a Clear and Convincing Argument; Factor 3, Strategies for Improving one's English Speaking skills; Factor 4, Strategies for Doing Presentations in English. Appendix $\mathrm{C}$ shows the number and name of each factor, the number and general content of every strategy item that loads adequately on that factor, the specific loading of each of the strategy items, and the average frequency of use of the items.

Table 2: Factors of the Speaking Strategy Use Sub-scale

\begin{tabular}{lllll}
\hline Factor & & Mean & SD & Alpha \\
\hline 1 & $\begin{array}{l}\text { Strategies for Seeking Opportunities } \\
\text { to Speak in Class }\end{array}$ & $3 . .49$ & 1.18 & 0.84 \\
& $\begin{array}{l}\text { Strategies for Making a Clear and } \\
\text { Convincing Argument }\end{array}$ & 3.44 & 1.14 & 0.73 \\
3 & $\begin{array}{l}\text { Strategies for Improving English } \\
\text { Speaking Skills }\end{array}$ & 3.71 & 1.19 & 0.77 \\
\hline & $\begin{array}{l}\text { Strategies for Doing Presentations in } \\
\text { English }\end{array}$ & 3.60 & 1.22 & 0.71 \\
\hline
\end{tabular}


Factor One, Strategies for Seeking Opportunities to Speak in Class, includes various strategies that can help learners seek opportunities to speak in class. This factor includes five strategies; four are cognitive strategies and one is an effective strategy. Two strategies are about getting a chance to speak in class: Volunteer to answer teacher's questions (S09) and Raise hands again if fails to get a chance to speak (S14). Two strategies are used for finding an angle to join the classroom conversation, and they are paired-up strategies: Build upon classmates' remarks (S11) and Listen to classmates to join conversations (S 10). Finally, one strategy is to encourage oneself to speak even when there are difficulties (S15, Encourage oneself to speak). All combined, those strategies are used by the learner to seek opportunities to speak in class. Therefore, the factor can be referred to as Strategies for Seeking Opportunities to Speak in Class.

Factor Two, Strategies for Making a Clear and Convincing Argument, includes strategies that can help the learner make a clear and convincing argument. Those strategies help the learner in different aspects: pronunciation, main argument points, and rhetorical moves. For example, learners can notice how people agree and disagree from each other in English (S13) and learn from them to make their own stance; learners can think about how to make their points clear and precise (S08); learners can put stress on important words (S12) to emphasize their points; and finally learners can prepare key points beforehand to share (S07) during a class or a presentation. This factor is mainly concerned with making a good argument.

Factor Three, Strategies for Improving one's English Speaking Skills, includes strategies that help learners improve their English speaking skills. This factor mostly includes what learners can do daily to improve their English speaking. Most of those actions can happen outside a classroom. Learners can expand their vocabularies (S03), pay attention to pronunciation (S01), read aloud academic materials (S02), and notice how people explain complicated ideas (S04). Finally, they can seek opportunities to interact with people in English (S05).

Factor Four, Strategies for Doing Presentations in English, has five strategies that can be used to help the learner present in academic English. They include strategies that can be used before, 
during, and after the presentations. The learner first can seek opportunities to present (S16); then, he or she can rehearse before presenting (S17); next he or she can pay attention to the audience's reactions during the presentation (S18); after the presentation, he or she will reflect on it and can plan to improve next time (S19); and if the presentation goes well, the learner can praise or reward himself or herself (S20).

\section{Reliability of the instrument}

The reliability of the 39 items of the final version was examined by Cronbach's alpha. The overall listening and speaking scale has a Cronbach's alpha of 0.923; the listening subscale has a Cronbach's alpha of 0.875 ; the speaking subscale has a Cronbach's alpha of 0.891 . The above indicate a highly acceptable internal consistency.

\section{DISCUSSION AND CONCLUSIONS}

The study has made a significant contribution by developing and validating the ASESS, which is the first tool for assessing academic spoken English strategy use of non-native English speaking students at the graduate level. The main conclusion of this study is that it is a validated and reliable measure. Besides being a research tool that fills a gap in the literature, it can be used for students' self-assessment, first-day and exit assessment for strategy instruction courses or workshops, and also for teachers' references. By filling out the questionnaire, students are more aware of the importance of using those strategies to help them improve their academic spoken English proficiency. The participants of this study have revealed in the comments they wrote on the survey that by taking the survey, they are inspired to think more about their own spoken English and to use more of those strategies. This survey will also be very useful when educators want to create "learner profiles" of their students. As explained before, the survey does not include strategies that help the learner avoid finishing certain communicative tasks directly, such as compensation strategies that learners use to compensate for their limited capacities to communicate in the target language. Those strategies can be included in a future expanded version of the survey. 


\section{Appendix A: \\ Academic Spoken English Strategies Survey (ASESS)}

Are you a non-native English speaking graduate student? Check your answer.

Yes and I am a doctoral student.

Yes and I am a Master's student.

Female $\square \quad$ Male $\square$

What is your academic discipline?

What is your country of origin?

Your e-mail address (optional, for entering into the drawing for prizes)

For the following scales, $\mathbf{1}=$ never or almost never, $\mathbf{2}=$ =rarely, $\mathbf{3}=$ sometimes, $\mathbf{4}=$ often, $\mathbf{5}=$ always or almost always, please circle one.

Academic English Listening

\begin{tabular}{|c|c|c|}
\hline 1 & $\begin{array}{l}\text { I try to relax before the class (presentation) so I } \\
\text { can concentrate later. }\end{array}$ & 12345 \\
\hline 2 & $\begin{array}{l}\text { I arrive early for classes or presentations and } \\
\text { choose to sit where I can hear the speaker } \\
\text { (instructor) better. }\end{array}$ & 12345 \\
\hline 3 & $\begin{array}{l}\text { I check the meaning of key words or concepts } \\
\text { before a lecture. }\end{array}$ & 12345 \\
\hline 4 & $\begin{array}{l}\text { I decide in advance what my listening purpose } \\
\text { is and I listen with that purpose in mind. }\end{array}$ & 12345 \\
\hline 5 & $\begin{array}{l}\text { Before I listen, I try to predict what new things } \\
\text { I might learn, based on what I already know } \\
\text { about the topic. }\end{array}$ & 12345 \\
\hline 6 & $\begin{array}{l}\text { I infer (guess) the meaning of unknown words } \\
\text { from the contexts of the speech. }\end{array}$ & 12345 \\
\hline 7 & If I don't understand a word or something else & 122345 \\
\hline
\end{tabular}




\begin{tabular}{|c|c|c|}
\hline & $\begin{array}{l}\text { that I hear, I use my laptop to check about it on- } \\
\text { line. }\end{array}$ & \\
\hline 8 & $\begin{array}{l}\text { As I listen, I make predictions about what the } \\
\text { speaker will talk about next. }\end{array}$ & 12345 \\
\hline 9 & $\begin{array}{l}\text { While I listen, I periodically check whether the } \\
\text { information is making sense to me. }\end{array}$ & 12345 \\
\hline 10 & $\begin{array}{l}\text { As I listen, I will adjust my understanding if I } \\
\text { realize my understanding is not correct. }\end{array}$ & 12345 \\
\hline 11 & $\begin{array}{l}\text { I pay attention to the speaker's facial } \\
\text { expressions, gestures and voice changes. }\end{array}$ & 12345 \\
\hline 12 & $\begin{array}{l}\text { I encourage myself if I feel frustrated because I } \\
\text { cannot understand certain parts of the speech. }\end{array}$ & 12345 \\
\hline 13 & $\begin{array}{l}\text { When my mind wanders, I try to get back on } \\
\text { track and recover my concentration. }\end{array}$ & 12345 \\
\hline 14 & $\begin{array}{l}\text { When I have difficulty understanding what I } \\
\text { hear, I keep concentrating without giving up. }\end{array}$ & 12345 \\
\hline 15 & $\begin{array}{l}\text { If I hear a word that I do not know, I quickly } \\
\text { judge whether I need to check its meaning, } \\
\text { without losing track of the speech. }\end{array}$ & 12345 \\
\hline 16 & $\begin{array}{l}\text { I identify what I don't understand about the } \\
\text { speech, and ask a precise question to solve the } \\
\text { problem. }\end{array}$ & 12345 \\
\hline 17 & $\begin{array}{l}\text { I summarize (in my head or in writing) } \\
\text { important information that I have heard. }\end{array}$ & 12345 \\
\hline 18 & $\begin{array}{l}\text { After the lecture (presentation), I reflect on how } \\
\text { much I understood and how I can improve next } \\
\text { time. }\end{array}$ & 12345 \\
\hline 19 & $\begin{array}{l}\text { After a lecture or presentation, I discuss with } \\
\text { the lecturer (presenter) or somebody else. }\end{array}$ & 12345 \\
\hline
\end{tabular}

Academic English Speaking

\begin{tabular}{|l|l|lllll|}
\hline 1 & $\begin{array}{l}\text { I pay attention to my pronunciation and try to } \\
\text { sound as clear as possible. }\end{array}$ & \begin{tabular}{lllll}
1 & 2 & 3 & 4 & 5 \\
\hline
\end{tabular}
\end{tabular}




\begin{tabular}{|c|c|c|}
\hline 2 & $\begin{array}{l}\text { I read aloud materials in my field to practice } \\
\text { speaking in academic English. }\end{array}$ & 12345 \\
\hline 3 & $\begin{array}{l}\text { I deliberately try to expand my academic } \\
\text { vocabulary in English. }\end{array}$ & 12345 \\
\hline 4 & $\begin{array}{l}\text { I pay attention to how people in my field } \\
\text { explain complicated ideas in English. }\end{array}$ & 12345 \\
\hline 5 & $\begin{array}{l}\text { I seek opportunities to interact with classmates, } \\
\text { professors and others in academic settings } \\
\text { (classes, conferences, group activities...) }\end{array}$ & 12345 \\
\hline 6 & $\begin{array}{l}\text { I try to learn from good presenters or classmates } \\
\text { who speak clearly and convincingly. }\end{array}$ & 12345 \\
\hline 7 & I prepare key points to share in class. & 12345 \\
\hline 8 & $\begin{array}{l}\text { Before I speak in class, I think about how to } \\
\text { make my message clear and precise. }\end{array}$ & 12345 \\
\hline 9 & $\begin{array}{l}\text { I volunteer to answer teacher's questions in } \\
\text { class. }\end{array}$ & 12345 \\
\hline 10 & $\begin{array}{l}\text { During class discussions, I listen attentively to } \\
\text { what my classmates say in order to join the } \\
\text { conversation. }\end{array}$ & 12345 \\
\hline 11 & $\begin{array}{l}\text { I build upon what my classmates have said and } \\
\text { join in the class discussion. }\end{array}$ & 12345 \\
\hline 12 & $\begin{array}{l}\text { When I speak, I put the stress on important } \\
\text { words (speak them louder or for longer time). }\end{array}$ & 12345 \\
\hline 13 & $\begin{array}{l}\text { I pay attention to how people agree and } \\
\text { disagree with each other in classes and at } \\
\text { academic conferences. }\end{array}$ & 12345 \\
\hline 14 & $\begin{array}{l}\text { If I raise my hand and fail to get the chance to } \\
\text { speak in class, I will raise it again without } \\
\text { giving up. }\end{array}$ & 12345 \\
\hline 15 & $\begin{array}{l}\text { Although I know my English is not perfect, I } \\
\text { encourage myself to speak up when I have } \\
\text { something meaningful to say. }\end{array}$ & 12345 \\
\hline 16 & $\begin{array}{l}\text { I seek opportunities to present (such as at } \\
\text { conferences). }\end{array}$ & 12345 \\
\hline 17 & $\begin{array}{l}\text { I rehearse before presenting in class or at a } \\
\text { conference. }\end{array}$ & 12345 \\
\hline
\end{tabular}




\begin{tabular}{|c|c|c|}
\hline 18 & $\begin{array}{l}\text { I pay attention to my audience's reactions while } \\
\text { I speak and adjust accordingly. }\end{array}$ & 122345 \\
\hline 19 & $\begin{array}{l}\text { After a class (or a presentation), I reflect on } \\
\text { how I } \\
\text { participated in the class or how I presented, and } \\
\text { think about } \\
\text { how to improve. }\end{array}$ & 12345 \\
\hline 20 & $\begin{array}{l}\text { If I feel satisfied with my class participation or } \\
\text { presentation, I will praise or reward myself. }\end{array}$ & 12345 \\
\hline
\end{tabular}

\section{REFERENCES}

Allum, J. (2013). CGS international graduate admissions survey, phase III: Final offer of admission and enrollment. Washington, DC: Council of Graduate Schools. Retrieved from http://www.cgsnet.org

Cheng, L., Myles, J., \& Curtis, A. (2004). Targeting language support for non-native English-speaking graduate students at a Canadian university. TESL Canada Journal, 21, 50-71.

Choi, T. (2006). Asian international students' academic adjustment in a U.S. graduate school and Stanton-Salazar's framework. Pacific Asian Education, 18(2), 51-68.

Cohen, A. D. \& Macaro, E. (Eds.), Language learner strategies: Thirty years of research and practice. Oxford, England: Oxford University Press.

Cohen, A. D. (1998). Strategies in learning and using a second language. London, England: Longman.

Dörnyei, Z. (2006). Individual differences in second language acquisition. AILA Review, 19, 42-68.

Erichsen, A. \& Boliger, D. (2011). Towards understanding international graduate student isolation in traditional and online environments. Education Tech Research Development, 59, 309-326.

Goh, C. (1998). How ESL learners with different listening abilities use comprehension strategies and tactics. Language Teaching Research, 2(2), 124-147.

Goh, C. (2002). Exploring listening comprehension tactics and their interaction patterns. System, 30(2), 185-206. 
Green, J. M., \& Oxford, R. L. (1995). A closer look at learning strategies, L2 proficiency, and gender. TESOL Quarterly, 29 (2), 261-297.

Halic, O., Greenberg, K., \& Paulus, T. (2009). Language and academic identity: A study of the experiences of non-native English speaking international students. International Education, 11, 73-93.

Huang, L. (2010). Do different modalities of reflection matter? An exploration of adult second-language learners' reported strategy use and oral language production. System, 38(2). 245261.

Kim, S. (2006). Academic oral communication needs of East Asian international graduate students in non-science and nonengineering fields. English for Specific Purposes, 25, 479-489. Kyungsim, H. \& Leavell, A. (2006). Language learning strategy use of ESL students in an intensive English learning context. System, 34(3), 399-415.

Ma, R., \& Oxford, R. (2014). A diary study focusing on listening and speaking: The evolving interaction of learning styles and learning strategies in a motivated, advanced ESL learner. System, 43, 101-113.

Macaro, E., Graham, S., \& Vanderplank, R. (2007). A review of listening strategies: Focus on sources of knowledge and on success. In A. Cohen \& E. Macaro (Eds.), Language learner strategies: Thirty years of research and practice. Oxford, England: Oxford University Press.

Nakatani, Y \& Goh, C. (2007). A review of oral communication strategies: Focus on interactionist and psycholinguistic perspectives. In A. Cohen \& E. Macaro (Eds.), Language learner strategies: Thirty years of research and practice. Oxford, England: Oxford University Press.

Oxford, R. L. (1990). Language learning strategies: What every teacher should know. Boston, MA: Heinle \& Heile publishers.

Oxford, R. L. \& Schramm, K. (2007). Bridging the gap between psychological and sociocultural perspectives on L2 learner strategies. In A. Cohen \& E. Macaro (Eds.), Language 
learner strategies: Thirty years of research and practice. Oxford, England: Oxford University Press.

Oxford, R. L. (2011). Teaching and researching language learning strategies. Upper Saddle River, NJ: Longman.

Rohani, S. (2006). Impact of task-based learning on Indonesian tertiary EFL students' employment of oral communication strategies. International Journal of Interdisciplinary Social Sciences, 87-101.

Vandergrift, L. (1997). The Cinderella of communication strategies: Reception strategies in interactive listening. The Modern Language Journal, 81, 494-505.

Vandergrift, L. (2003). Orchestrating strategy use: Toward a model of the skilled second language listener. Language Learning, 53 (3), 463-496.

Vandergrift, L., Goh, C., Mareschal, C., \& Tafaghodtari, M. (2006). The metacognitive awareness listening questionnaire: Development and validation. Language Learning, 56 (3), 431-462.

Zappa-Hollman, S. (2007). Academic presentations across postsecondary contexts: The discourse socialization of non-native English speakers. Canadian Modern Language Review, 63 (4), 455-485.

Zhang, D., \& Goh, C. M. (2006). Strategy knowledge and perceived strategy use: Singaporean students' awareness of listening and speaking strategies. Language Awareness, 15(3), 199219.

RUI M. SCHROEDER, $\mathrm{PhD}$, is a visiting lecturer at the University of the Pacific. Dr. Schroeder's research work focuses on language learning strategies, language pedagogies, and language learners. She has taught ESL, first year seminars, and Chinese language courses at different educational institutions. Email: rma@pacific.edu

Manuscript submitted: November 5, 2014

Manuscript Revised: January 4, 2015 Accepted for publication: March 5, 2015 